\title{
Due Diligence and Supply Chain Responsibilities in Specific Instances
}

\author{
The Compatibility of the Dutch National Contact Point's Decisions With the OECD Guidelines \\ for Multinational Enterprises in the Light of Decisions Made by the UK, German, Danish and \\ Norwegian National Contact Points
}

Sander van 't Foort*

\begin{abstract}
Since the introduction of a human rights chapter in the 2011 OECD Guidelines for Multinational Enterprises, National Contact Points (NCPs) have been increasingly dealing with specific instances referring to human rights violations by companies. According to the Organisation for Economic Cooperation and Development (OECD), the human rights provisions are the most cited provisions of the Guidelines. Specific instances include allegations such as a company's failure to implement human rights due diligence, to apply the principles of free, prior and informed consent, to take supply chain responsibility, and/or to comply with the right to cultural heritage. Of all topics, human rights due diligence and human rights supply chain responsibilities are most commonly referred to in complaints based on the Guidelines. This article focuses on how NCPs have handled these topics of human rights due diligence and supply chain responsibility in specific instances. The Dutch NCP has been selected because it is celebrated in literature as the 'gold standard' because of its composition including independent members, its forward-looking approach, and because it is one of the most active NCPs in the world. All decisions of the Dutch NCP concerning these two topics are analysed in the light of the decisions of four other NCPs (UK, Denmark, Germany and Norway). A doctrinal methodology is used to analyse similarities and differences between the argumentations of the five NCPs.
\end{abstract}

Keywords: due diligence, supply chain, OECD, NCP, specific instance

\section{Introduction}

1.1 Introduction

In May 2019, the Meeting of the Council of the Organisation for Economic Cooperation and Development (OECD) at the Ministerial Level (MCM) stressed the

Sander van 't Foort is Lecturer at Nyenrode Business University. The author is thankful for the invaluable feedback provided by Prof. Dr. T.E. Lambooy and Prof. Dr. R. Jeurissen on this article. importance of policy coherence. The MCM recommended all governments adhering to the OECD Guidelines for Multinational Enterprises (MNE Guidelines) to ensure that National Contact Points (NCPs) should receive the necessary support and visibility within their government to 'promote policy coherence on responsible business conduct' (RBC). ${ }^{1}$ This recommendation was based on the MCM's progress report on NCPs, which listed policy coherence among the top five issues. $^{2}$

Upon request from a number of parliamentarians, ${ }^{3}$ the Dutch government decided to attach consequences to the Dutch NCP's decisions in specific instances to increase policy coherence. Whenever the Dutch NCP comes to the conclusion that a multinational enterprise (MNE) does not respect the MNE Guidelines and is not acting responsibly, the government may decide to exclude this company from grants, export credits and trade missions or may take it into account in sustainable procurement. ${ }^{4}$ As such, NCPs and their domestic governments play an important role in the advancement of RBC. This is especially true for human rights issues.

Since the introduction of a human rights chapter in the 2011 MNE Guidelines by the OECD, NCPs are increasingly dealing with specific instances referring to human rights violations by MNEs. ${ }^{5}$ According to the OECD, the human rights provisions are the most cited provisions of the MNE Guidelines since their last revision in 2011. ${ }^{6}$ Specific instances include allegations such as a company's failure to implement human rights due

1. OECD, Progress Report on National Contact Points for Responsible Business Conduct: Meeting of the OECD Council at Ministerial Level (2019), at 10-11 and 14.

2. OECD (2019), above n. 1, at 11-12.

3. Kamerstukken // 2009/10, 26 485, nr. 93.

Kamerstukken I/ 2010/11, 26 485, nr. 101, at 9.

5. J. Ruggie and T. Nelson, 'Human Rights and the OECD Guidelines for Multinational Enterprises: Normative Innovations and Implementation Challenges', Corporate Social Responsibility Initiative Working Paper 2015:66, at 14 .

6. OECD, Implementing the OECD Guidelines for Multinational Enterprises: The National Contact Points from 2000 to 2015 (2016), at 39-40. 
diligence policies, ${ }^{7}$ to take supply chain responsibility, ${ }^{8}$ and/or to comply with the right to cultural heritage. ${ }^{9}$ Of all topics, human rights due diligence and human rights supply chain responsibilities are the most commonly referred to in complaints based on the MNE Guidelines. ${ }^{10}$

This article focuses on how NCPs have handled these topics of human rights due diligence and supply chain responsibilities in specific instances. The decisions of the Dutch NCP are analysed in the light of the decisions of four other NCPs (i.e. the United Kingdom (UK) NCP, German NCP, Danish NCP and Norwegian NCP) (see Section 3.1). The central research question is:

How are the MNE Guidelines provisions regarding human rights due diligence and supply chain responsibilities interpreted by the Dutch NCP in the light of the decisions of the UK NCP, German NCP, Danish NCP and Norwegian NCP?

Although a limited amount of literature delves into the statistics of human rights-related specific instances (see Section 1.3), no articles systematically analyse NCP decisions on human rights. Just a few articles and reports examine the argumentation of an NCP in a few cases. ${ }^{11}$ This article attempts to address this gap in the literature by systematically examining more than forty specific instances to tease out differences and similarities in argumentation.

In the remainder of this section, this article briefly introduces the MNE Guidelines (Section 1.2), NCPs and the specific instance procedure (Section 1.3), the Dutch NCP (Section 1.4), human rights addressed in specific instances (Section 1.5) and the effectiveness criterion 'compatibility with the MNE Guidelines' and the concept of functional equivalence (Section 1.6). Next, this article presents a theoretical framework (Section 2) and explains the methodology applied (Section 3), followed by the author's findings (Section 4), discussion (Section 5) and conclusions (Section 6).

7. Danish NCP, Danish NGO v. Multinational Enterprise (Denmark) (2014).

8. UK NCP, IUF v. British American Tobacco (2016)

9. Dutch NCP, FIVAS, the Initiative to Keep Hasankeyf Alive and Hasankeyf Matters v. Bresser (2018).

10. At least for the NCPs examined in this study (see Section 3). Cf. OECD Watch, Remedy Remains Rare: An Analysis of 15 Years of NCP Cases and Their Contribution to Improve Access to Remedy for Victims of Corporate Misconduct (2015), at 12; Ruggie and Nelson, above n. 5, at 22-4.

11. L. Backer, 'Rights and Accountability in Development (Raid) v Das Air and Global Witness $\vee$ Afrimex: Small Steps Toward an Autonomous Transnational Legal System for the Regulation of Multinational Corporations', 10 Melbourne Journal of International Law 2 (2009); OECD Watch, 10 Years on: Assessing the Contribution of the OECD Guidelines for Multinational Enterprises to Responsible Business Conduct (2010); OECD Watch (2015), above n. 10

\subsection{The OECD Guidelines for Multinational Enterprises}

In 1976 the OECD promulgated the Declaration on International Investment and Multinational Enterprises (MNE Declaration), part of which were the MNE Guidelines. ${ }^{12}$ All OECD member states ${ }^{13}$ recommended the MNEs operating in or from their territories to observe the MNE Guidelines. ${ }^{14}$ After their inception, the MNE Guidelines have been revised five times, their latest revision being in 2011. Over the years, the MNE Guidelines have been expanded and now include eleven chapters. Each chapter contains recommendations for MNEs pertaining to various areas, such as the protection of the environment, combatting bribery, the disclosure of information and the advancement of human rights. ${ }^{15}$

As part of the MNE Declaration, the MNE Guidelines are considered as a declaration (the qualification as 'guidelines' being a misnomer). ${ }^{16}$ Since declarations do not have any legal status according to the 1960 Convention on the OECD, the convention constituting the OECD ${ }^{17}$ the MNE Guidelines are characterised as soft law. However, many rules enshrined in the MNE Guidelines are also reflected in international law and can therefore be characterised as hard law. The upshot of this intermingling of soft and hard law is that the recommendations contained in the MNE Guidelines are, in fact, hybrid in nature, often reflecting hard law rules yet also being part of a soft law instrument (i.e. the MNE Guidelines). ${ }^{18}$

\subsection{National Contact Points and the Specific Instance Procedure}

The MNE Guidelines are accompanied by a unique grievance mechanism, referred to as 'specific instances'. ${ }^{19}$ Specific instances are procedures set in place to resolve disputes that arise within the framework of the

12. OECD, Declaration on International Investment and Multinational Enterprises (1976).

13. At that time, the member states were Australia, Austria, Belgium, Canada, Denmark, Finland, France, the Federal Republic of Germany, Greece, Iceland, Ireland, Italy, Japan, Luxembourg, the Netherlands, New Zealand, Norway, Portugal, Spain, Sweden, Switzerland, the UK and the US. Turkey was the only member state that decided to adhere to the declaration a few years later, in 1981 (OECD, Mid-term Report on the 1976 Declaration and Decisions (1982), at 8).

14. OECD (1976), above n. 12, at Section I.

15. OECD, OECD Guidelines for Multinational Enterprises (2011a).

16. H. Baade, 'The Legal Effects of Codes of Conduct for Multinational Enterprises', in N. Horn (eds.), Legal Problems of Codes of Conduct for Multinational Enterprises (1980) 3, at 19.

17. Cf. Art. 5 Convention on the Organisation for Economic Co-operation and Development (1960); T. Vogelaar, 'The OECD Guidelines: Their Philosophy, History, Negotiation, Form, Legal Nature, Follow-up Procedures and Review', in N. Horn (eds.), Legal Problems of Codes of Conduct for Multinational Enterprises (1980) 127, at 132-3.

18. S. van 't Foort, 'The History of National Contact Points and the OECD Guidelines for Multinational Enterprises', 25 Journal of the Max Planck Institute for European Legal History 195, at 206-7 (2017).

19. B. Maheandiran, 'Calling for Clarity: How Uncertainty Undermines the Legitimacy of the Dispute Resolution System Under the OECD Guidelines for Multinational Enterprises', 20 Harvard Negotiation Law Review 205, at 211 (2015); R. Nieuwenkamp, Translating 'Human Rights Speak' into 'Business Speak' (2016). 


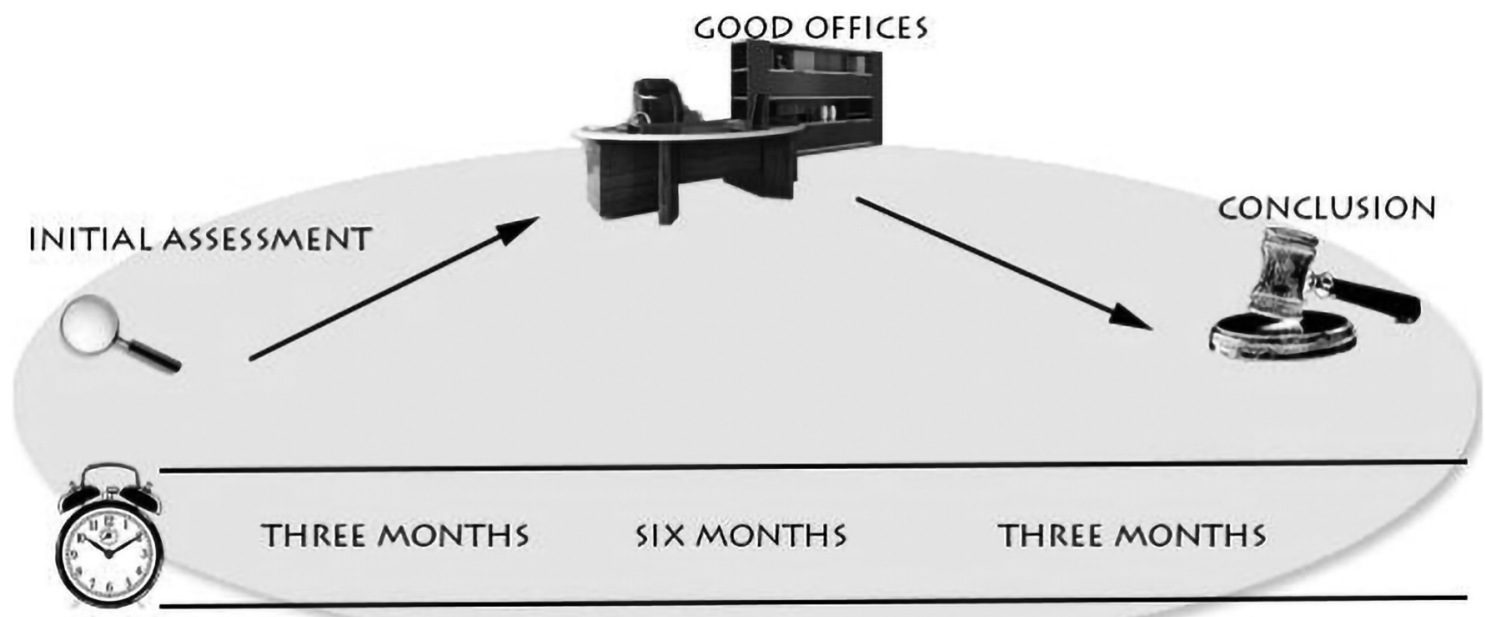

* S. van 't Foort and J. Wilde-Ramsing, 'A Comparative Analysis of the Dutch Specific Instance Procedure', 4 Nederlands-Vlaams Tijdschrift voor Mediation en Conflictmanagement 16 (2015).

MNE Guidelines in a non-adversarial manner through, for instance, mediation or conciliation. ${ }^{20}$ The institutions responsible for handling specific instances are NCPs. NCPs are established by the governments of thirty-six OECD member states and twelve adhering countries. First introduced as 'Contact Points' in 1979, to 'usefully contribute to the solution of problems relating to the MNE Guidelines', ${ }^{21}$ NCPs have evolved over the years and are now tasked with undertaking promotional activities, handling enquiries and contributing to the resolution of issues that relate to the implementation of the MNE Guidelines in specific instances. ${ }^{22}$ Since 1984, member states and other adhering countries are legally obliged to set up an NCP in their countries to 'further the effectiveness of the MNE Guidelines' ${ }^{23}$

A total of forty-eight NCPs formally exist in the world. ${ }^{24}$ According to the latest OECD statistics available, these NCPs have collectively received 425 notifications to start a specific instance between 2000 and $2017 .{ }^{25}$ In a more detailed stock-taking report of specific instances between 2000 and 2015, the OECD shows that half of all specific instances were dealt with by six NCPs, of which three, namely the UK NCP (for-

OECD, Decision of the Council on the OECD Guidelines for Multinational Enterprises 25 May 2011 (2011b), at Procedural Guidance, Section I, C.2.

21. OECD, Report of the Committee on International Investment and Multinational Enterprises on the Review of the 1976 (1979), at 79.

22. OECD (2011b), above n. 20, at Section I.1.

23. Ibid

24. NCPs exist in Argentina, Australia, Austria, Belgium, Brazil, Canada, Chile, Colombia, Costa Rica, Czech Republic, Denmark, Egypt, Estonia, Finland, France, Germany, Greece, Hungary, Iceland, Ireland, Israel, Italy, Japan, Jordan, Kazakhstan, Korea, Latvia, Lithuania, Luxembourg, Mexico, Morocco, Netherlands, New Zealand, Norway, Peru, Poland, Portugal, Romania, Slovak Republic, Slovenia, Spain, Sweden, Switzerland, Tunisia, Turkey, Ukraine, United Kingdom, and the United States (OECD, List of National Contact Points, https:// mneguidelines.oecd.org/ncps/ (last visited 29 April 2019)).

25. OECD, Cases Handled by the National Contact Points for the OECD Guidelines for Multinational Enterprises (2017), at 2. ty-five specific instances), the United States (US) NCP (forty-three specific instances) and the Dutch NCP, (twenty-eight specific instances) handled most cases. ${ }^{26}$ A typical specific instance consists of three phases: (i) an initial assessment; (ii) the procedure of offering good offices; and (iii) the conclusion (see Figure 1).

The initial assessment begins with a notification submitted to an NCP by a party claiming that another party, mostly an MNE, is not acting in conformity with the MNE Guidelines. The notifying party could be from the business community, a worker organisation, a nongovernmental organisation (NGO), or may be another 'interested party'. When assessing the notification, the NCP checks whether the notification is bona fide and relevant to the implementation of the MNE Guidelines. The initial assessment is completed when the NCP decides whether the issue merits further consideration or not. The expected time frame for the initial assessment is three months. ${ }^{27}$

Whenever the notification warrants further examination, the NCP offers its services. The NCP can solicit advice from other parties, such as NGOs, other NCPs or government authorities at this stage. Upon agreement of the parties involved in the specific instance, the NCP can offer mediation or conciliation services. If a notification does not warrant further examination, the NCP will issue a statement describing the issues raised and the reasons underpinning its decision. The expected time frame for this stage is six months. ${ }^{28}$

At the final stage of the specific instance, mediation may fail or succeed. If mediation fails, the NCP will issue a statement entailing, among others, the issues raised. If appropriate, the NCP may also give recommendations

26. OECD (2016), above n. 6, at 29 and 41.

27. OECD (2011b), above n. 20, at Procedural Guidance, Section I, C.1 and Commentaries 25-7.

28. Ibid., at Procedural Guidance, Section I, C.2 and Commentaries 28-30. 
to the parties concerned. When mediation succeeds, parties have reached an agreement, and the NCP issues a report. This report contains information about the issues raised and may also contain the agreement. After the final stage, parties can request the NCP to follow up on the implementation of the agreement or recommendations. This third and final stage normally takes three months. ${ }^{29}$

\subsection{The Dutch NCP}

Praised as the 'gold standard' by former UN Special Representative on Business and Human Rights, John Ruggie, because of its institutional structure, ${ }^{30}$ the Dutch NCP comprises independent and advisory members. Independent members have various backgrounds, with active careers in, for instance, the academic world or business community. The advisory members work for the Dutch government. Currently, they represent the Ministry of Economic Affairs and Climate Policy, the Ministry of Social Affairs and Employment, the Ministry of Infrastructure and Water Management and the Ministry of Foreign Affairs. ${ }^{31}$ According to the OECD's typology, the Dutch NCP has an 'independent agency' structure, meaning that to a certain degree it acts independently of the Dutch government. ${ }^{32}$ The independent members are in the lead and handle specific instances without any governmental interference.

Since the mandate of the Dutch NCP was extended and revised in 2014, two other unique features have been added to the Dutch NCP's repertoire. The Dutch NCP may now check whether international RBC sector agreements are in conformity with the MNE Guidelines and may, upon request of the Dutch Government, conduct sector-wide assessments concerning the overall observance by Dutch companies of the MNE Guidelines. ${ }^{33}$

Specific instances handled by the Dutch NCP generally follow the same procedure set out by the OECD (see Section 1.3). Specific to the Dutch NCP's procedure are confidential meetings held with each party separately during the initial assessment phase. ${ }^{34}$ Less unique, but still noteworthy, is that the Dutch NCP sometimes ${ }^{35}$ conducts field visits, e.g. when the alleged non-observance of the MNE Guidelines took place in a non-adhering country to the MNE Guidelines. ${ }^{36}$ The Dutch NCP also ensures a follow-up to agreements reached between

29. Ibid., at Procedural Guidance, Section I, C.3 and Commentaries 31-41.

30. Kamerstukken // 2010/11, 26 485, nr. 101, 8 (Letter from the State Secretary of Economic Affairs, Agriculture and Innovation).

31. Dutch NCP, NCP, www.oecdguidelines.nl/ncp/ncp-members (last visited 21 April 2019).

32. OECD, Annual Report on the OECD Guidelines for Multinational Enterprises 2017 (2018a), at 28.

33. Government Decree NCP 2014 (Stcrt. 2014, nr. 19014). Cf. S. de Bruyn et al., Compliance of the Dutch Oil and Gas Sector to OECD Guidelines (2019).

34. Dutch NCP, Specific Instance Procedure: Dutch National Contact Point OECD Guidelines for Multinational Enterprises (2018), at 2.

35. Cf. Dutch NCP, Friends of the Earth v. Pilipinas Shell Petroleum Corporation (2009).

36. OECD (2011b), above n. 20, at Procedural Guidance, Commentaries 39. the parties, mostly one year after the agreement was reached. ${ }^{37}$

\subsection{Human Rights in Specific Instances}

Before the latest revision of the MNE Guidelines, in 2011, the employment and industrial relations provisions used to be the most cited of all provisions in the MNE Guidelines. Human rights were broadly defined by the General Principles chapter, but no specific human rights chapter existed yet. Since the introduction of a human rights chapter in the revised MNE Guidelines in 2011, the OECD has identified an upsurge of human rights-related instances (see Figure 2). These findings are corroborated by research done by OECD Watch, showing that most complaints filed by NGOs in the past fifteen years pertained to human rights issues. ${ }^{38}$ Overseeing a period between 2003 and 2014, Ruggie and Nelson analysed various human rights cases and came to a similar conclusion, finding a 'greater number and increased diversity' of human rights cases. ${ }^{39}$ In a similar vein, Khoury and Whyte analysed 402 specific instances between 2002 and 2016 and found that 'by far' the largest single category of specific instances handled by NCPs pertains to human rights. ${ }^{40}$

\subsection{Compatibility With the MNE Guidelines and Functional Equivalence}

The criterion 'compatibility with the MNE Guidelines' is central to the analysis of the five NCPs' decisions (see Section 3.3). Compatibility is one of the core effectiveness criteria for specific instances. According to the Procedural Guidance to the Decision of the Council, NCPs have to contribute to the resolution of specific instances in a manner that is compatible with the MNE Guidelines, meaning that NCPs should operate in accordance with the principles and standards contained in the [MNE] Guidelines'. ${ }^{41}$ This effectiveness criterion is used in this article as a yardstick to identify resemblances with or deviations from the MNE Guidelines by NCPs in their decisions.

'Functional equivalence' has not been defined by the MNE Guidelines, and not much guidance is provided either. $^{42}$ In the main, functional equivalence relates to NCPs functioning in a similar manner. In the past, 'commensurability' was a term often used to signify that NCPs should function equally. ${ }^{43}$ If this is not the case, a

37. Cf. Dutch NCP, FNV Eemshaven v. NUON Energy (follow-up statement) (2015); and Dutch NCP, Bart Stapert v. Mylan (follow-up statement) (2017)

38. OECD Watch (2015), above n. 10, at 12

39. Ruggie and Nelson, above n. 5, at 14

40. S. Khoury and D. Whyte, A Cautionary Tale of Regulating Corporate Human Rights Abuses (2017); S. Khoury and D. Whyte, 'A Manufactured Consensus', in Corporate Human Rights Violations (2017) 65.

41. OECD (2011b), above n. 20, at Procedural Guidance, Section I, C. Chapeau and Commentaries 22.

42. According to the Procedural Guidance to the Decision of the Council, NCPs aim to improve functional equivalence, by operating in a manner that is visible, accessible, transparent, and accountable (Ibid., at Procedural Guidance, Section I, Chapeau).

43. OECD, Report on the 2000 Review of the Guidelines (C(2000)96), at Annex 3, Annex to the Council Decision, preface. 


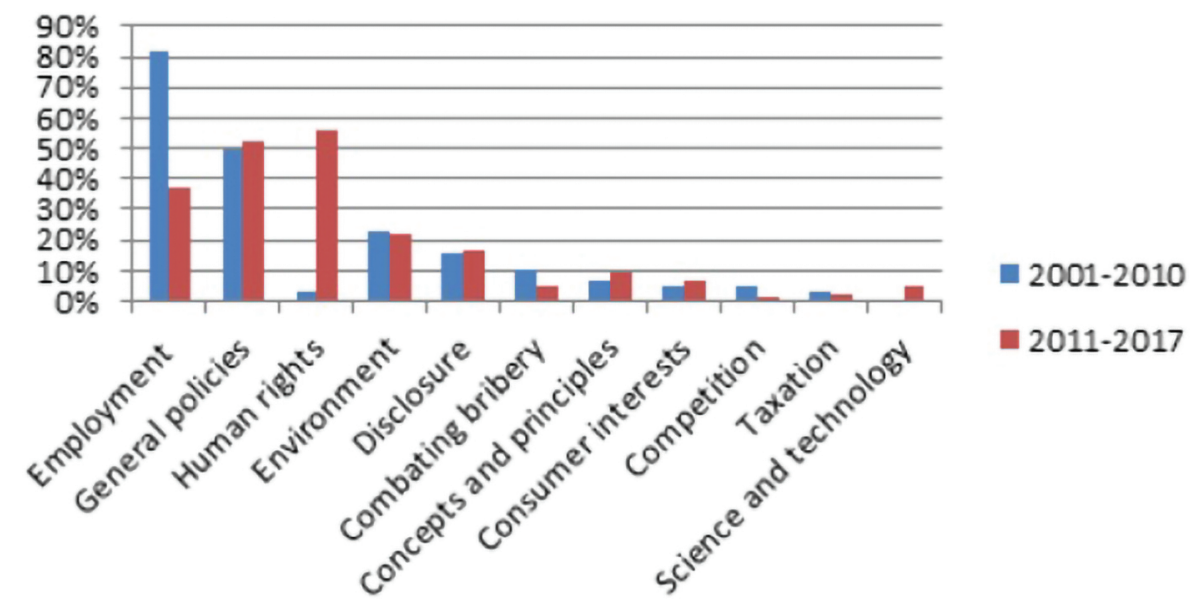

* OECD (2017), above n. 25, at 2 .

claimant could receive a different treatment in similar cases at various NCPs. Needless to say, incommensurability or functional non-equivalence may have negative consequences for the NCP system as a whole. Within the context of this research, functional equivalence refers to the coherence between the decisions of the NCPs and their consistent application across all NCPs.

\section{Theoretical Framework}

Human rights due diligence and human rights supply chain responsibilities form the focal point of this article. First, human rights due diligence is explained in Section 2.1. Then, human rights supply chain responsibilities are explained in Section 2.2. In each section the concept is explained, and the relevant provisions of the MNE Guidelines are presented.

\subsection{Human Rights Due Diligence}

Perhaps one of the most significant changes of the past decades in the human rights debate is the increased link between business and human rights. To a greater extent, MNEs are being held responsible for infractions of human rights. ${ }^{44}$ One of the tools an MNE can apply to ensure that it is respecting human rights is implementing human rights due diligence in its activities. ${ }^{45}$ Due diligence is defined by the MNE Guidelines as

the process through which enterprises can identify, prevent, mitigate and account for how they address their actual and potential adverse impacts as an inte-

44. M. Sepúlveda et al, Human Rights: Reference Handbook (2010), at 427.

45. K. Kryczka et al, 'The Importance of Due Diligence Practices for the Future of Business Operations in Fragile States', 9 European Company Law 125, at 125-32 (2012); T. Lambooy, Corporate Social Responsibility: Legal and Semi-Legal Frameworks Supporting CSR (2010) 277, at 277-342. gral part of business decision-making and risk management systems. ${ }^{46}$

A due diligence process is outlined by the OECD to advance RBC (see Figure 3). The first step is to embed RBC into an MNE's policies and management systems. This preliminary step establishes the prerequisite support for the actual due diligence process. The actual due diligence process commences with identifying actual or potential adverse impacts (step two). After identifying the impacts, an MNE is expected to cease, prevent or mitigate these impacts (step three). Follow-up by tracking the implementation and results of the measures taken in the previous step ensures that the right measures are being taken and helps improve the process when incorporating lessons learned (step four). Information about the conducted due diligence needs to be communicated. Publicising the impacts, measures taken, results of monitoring and possible remediation of the impacts or other information regarding the due diligence undertaken is part of communication about the process. Information can be disclosed in sustainability reports or on an MNE's website (step five). The final step in the due diligence process applies when an MNE identifies that it has caused or contributed to adverse impacts. Being aware of the harm inflicted, the MNE needs to redress its adverse impacts and is expected to provide for or cooperate with grievance mechanisms, such as NCPs. ${ }^{47}$

Human rights due diligence follows the same procedure as set out in Figure 3, although it is not exactly the same as due diligence. This distinction between due diligence and human rights due diligence is also made in the MNE Guidelines. While due diligence has a broad scope within the framework of the MNE Guidelines, i.e. all adverse impacts in discord with the provisions of the MNE Guidelines, the scope of human rights due dili-

46.

OECD (2011b), above n. 20, at Procedural Guidance, Commentaries on General Policies, 14

47. Ibid., at 15 and 21-35. 


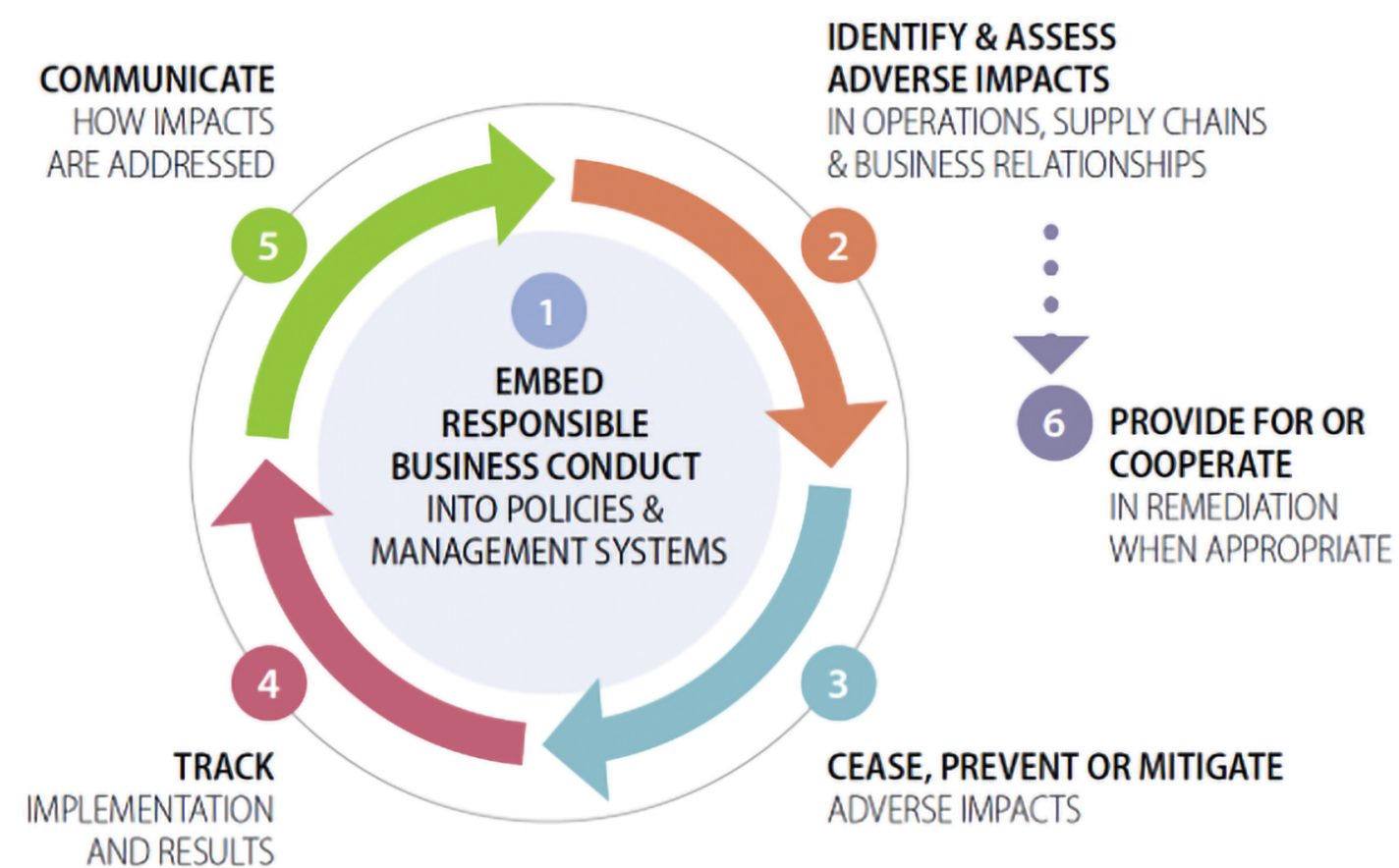

* OECD, OECD Due Diligence Guidance for Responsible Business Conduct (2018b), at 21.

Table 1 (Human rights) due diligence provisions in MNE Guidelines*

\begin{tabular}{lll}
\hline Provision & Text & Remarks \\
\hline II.10 & $\begin{array}{l}\text { [Enterprises should] carry out risk-based due diligence, for } \\
\text { example by incorporating it into their enterprise risk manage- } \\
\text { ment systems, to identify, prevent and mitigate actual and } \\
\text { potential adverse impacts ... and account for how these impacts } \\
\text { are addressed. The nature and extent of due diligence depend } \\
\text { on the circumstances of a particular situation. }\end{array}$ & $\begin{array}{l}\text { Applies to all chapters of the MNE } \\
\text { Guidelines except to Taxation, Sci- } \\
\text { ence and Technology and Competi- } \\
\text { tion chapters. * }\end{array}$ \\
& $\begin{array}{l}\text { [Enterprises should] carry out human rights due diligence as } \\
\text { appropriate to their size, the nature and context of operations } \\
\text { and the severity of the risks of adverse human rights impacts. }\end{array}$ & $\begin{array}{l}\text { Applies only to Human Rights chap- } \\
\text { ter. }\end{array}$ \\
\hline IV.5 & &
\end{tabular}

* OECD (2011a), above n. 15, at Provisions II.10 and IV.5.

** OECD (2011b), above n. 20, at Procedural Guidance, Commentaries on General Policies, 14.

gence is more limited, i.e. adverse human rights impacts conflicting with the human rights provisions of the MNE Guidelines. The former can be found in the General Policies chapter of the MNE Guidelines, the latter in the Human Rights chapter (see Table 1 for the provisions). A comprehensive overview of all human rightsrelated provisions can be found in Annex I.

\subsection{Human Rights Supply Chain Responsibilities}

On a global scale, supply chains have expanded, especially in sectors such as textile, food and agriculture. Working in supply chains has benefits, but also significant downsides. On the one hand, supply chains may contribute to economic growth, create jobs and alleviate poverty. On the other hand, supply chains may stimulate a race to the bottom and lead to a degradation of compliance with human rights, such as the exploitation of workers. Governments with insufficient resources may find it difficult to enforce laws and regulations on large MNEs, or their contract partners, that violate human rights, which may be exacerbated by (global) supply chains. ${ }^{48}$

For want of a definition of supply chains in the MNE Guidelines, this article applies the following definition of supply chains, derived from literature. A supply chain is

48. ILO, Reports of the Committee on Decent Work in Global Supply Chains: Resolution and Conclusions Submitted for Adoption by the Conference, 105th Session, Geneva, May-June 2016, at 1-6. 


\begin{tabular}{|c|c|c|}
\hline Provision & Text & Remarks \\
\hline II.12 & $\begin{array}{l}\text { [Enterprises should] seek to prevent or mitigate an adverse } \\
\text { impact where they have not contributed to that impact, when } \\
\text { the impact is nevertheless directly linked to their operations, } \\
\text { products or services by a business relationship. This is not } \\
\text { intended to shift responsibility from the entity causing an } \\
\text { adverse impact to the enterprise with which it has a business } \\
\text { relationship. }\end{array}$ & $\begin{array}{l}\text { Applies to all chapters of the MNE } \\
\text { Guidelines. }\end{array}$ \\
\hline II.13 & $\begin{array}{l}\text { In addition to addressing adverse impacts in relation to matters } \\
\text { covered by the [MNE] Guidelines, [enterprises should] encour- } \\
\text { age, where practicable, business partners, including suppliers } \\
\text { and subcontractors, to apply principles of responsible business } \\
\text { conduct compatible with the [MNE] Guidelines. }\end{array}$ & $\begin{array}{l}\text { Applies to all chapters of the MNE } \\
\text { Guidelines. }\end{array}$ \\
\hline IV.3 & $\begin{array}{l}\text { [Enterprises should] Seek ways to prevent or mitigate adverse } \\
\text { human rights impacts that are directly linked to their business } \\
\text { operations, products or services by a business relationship, even } \\
\text { if they do not contribute to those impacts. }\end{array}$ & $\begin{array}{l}\text { Applies only to Human Rights chap- } \\
\text { ter. }\end{array}$ \\
\hline
\end{tabular}

* OECD (2011a), above n. 15, at Provisions II.10 and IV.5.

an integrated process wherein a number of various business entities (i.e. suppliers, manufacturers, distributors, and retailers) work together in an effort to: (I) acquire raw materials, (II) convert these raw materials into specified final products, and (III) deliver these final products to retailers. ${ }^{49}$

The MNE Guidelines contain multiple provisions on supply chains (see Table 2). A distinction similar to that made between due diligence and human rights due diligence is made for supply chains. The General Provisions chapter of the MNE Guidelines contains a general supply chain recommendation, whereas the Human Rights chapter contains a specific recommendation for human rights-related responsibilities in supply chains.

Some terms of the (human rights) supply chain provisions can be further explained. In its commentaries, the MNE Guidelines state that 'contributed to' should be interpreted as 'substantial' contributions, meaning that an MNE 'causes, facilitates or incentivises' another entity to infringe the MNE Guidelines. ${ }^{50}$ The commentaries to the MNE Guidelines also contain an explanation of 'business relationship', which encompasses 'business partners, entities in the supply chain and any other nonstate or state entities'. ${ }^{51}$ An MNE can form a relationship with these parties, for example via franchising or subcontracting.

If an MNE has leverage over its business relationship, it should execute its leverage to the greatest extent possi-

49. B.M. Beamon, 'Supply Chain Design and Analysis: Models and Methods', 55 International Journal of Production Economics 281, at 281 (1998).

50. OECD (2011b), above n. 20, at Procedural Guidance, Commentaries on General Policies, 14

51. Ibid. ble. An impotent MNE can cooperate with other partners to increase leverage so that it can still relieve adverse (human rights) impacts. If possible, an MNE can also decide to temporarily suspend its relationship or - as a last resort - disengage. There may be practical barriers however. In very complex supply chains, it may be difficult - or even impossible - to define the supply chain responsibilities of an MNE. The MNE Guidelines acknowledge these practical constraints. ${ }^{52}$

\section{Methodology}

In this section the methodology is elaborated upon. Section 3.1 describes the selection of cases, Section 3.2 shows which databases were used for the data collection, and Section 3.3 explains the doctrinal method that was applied for data analysis.

\subsection{Selection of Cases}

When mapping the number of human rights related cases worldwide across all NCPs, a total of 181 cases were found over the period 2012-2018. ${ }^{53}$ The 181 human rights-related cases were dealt with by twentynine different NCPs. ${ }^{54} \mathrm{~A}$ meaningful analysis of these twenty-nine NCPs is difficult, considering that the NCPs are active in different continents, with disparate

52. OECD (2011b), above n. 20, at Procedural Guidance, Commentaries on General Policies, 17-23 and Commentaries on Human Rights, 42-3.

53. The closing date of this study was November 2018.

54. NCPs from Argentina, Australia, Austria, Belgium, Brazil, Canada, Chile, Columbia, Denmark, Finland, France, Germany, Italy, Japan, Luxembourg, Mexico, Morocco, the Netherlands, New Zealand, Norway, Peru, Poland, South Korea, Spain, Sweden, Switzerland, Turkey, the UK, and the US. 


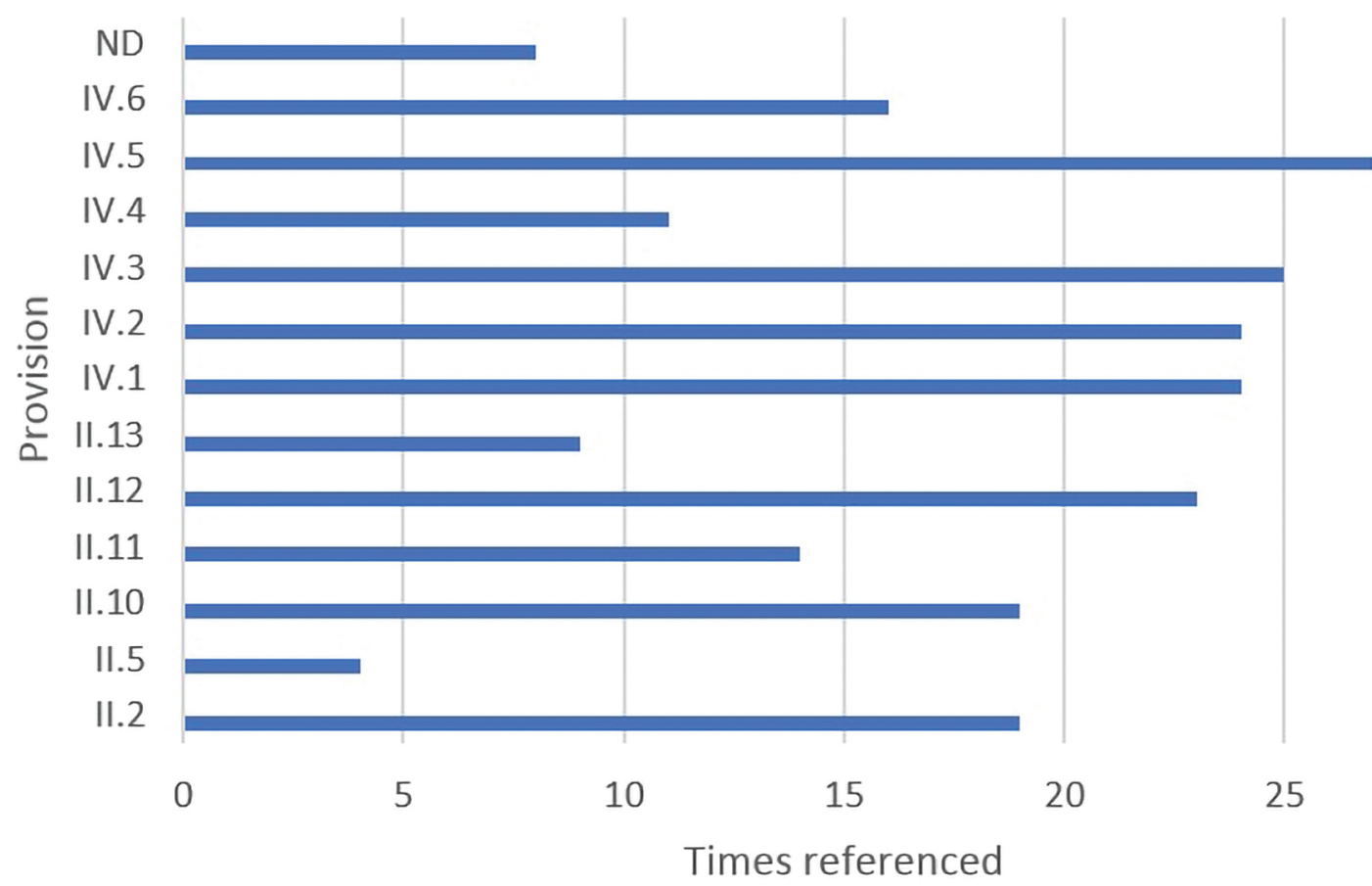

* ND stands for not disclosed. The exact provisions are not disclosed in these decisions.

institutional structures and have dissimilar procedures and cultures. This article therefore focuses on the Dutch NCP and selected a number of similar NCPs (the NCPs of the UK, Germany, Denmark, and Norway), allowing for an analysis of the Dutch NCP's procedures and outcomes in the light of those in the other countries. The total number of analysed cases of these five NCPs is forty-eight.

The other four NCPs were selected on the basis of their similarity with the Dutch NCP. The selected NCPs belong to the more progressive NCPs and are relatively independent in their set-up. Moreover, the other four countries are also comparable to the Netherlands in terms of being Western countries, each with progressive policies on $\mathrm{RBC}^{55}$ and supportive to the OECD and the implementation of the MNE Guidelines (cf. adhering countries that only have an NCP existing on paper).

Among the forty-eight cases examined, the (human rights) due diligence provisions (provisions II.10 and IV.5) and (human rights) supply chain responsibility provisions (provisions II.12 and IV.3) are the most cited (see Figure 4). ${ }^{56}$ For this reason, the cases that focus on these two themes have been selected. Another reason for selecting these provisions is that they offer the best chance of having a substantial number of decisions to analyse for similarities and differences in interpretation, i.e. to answer the research question. Of the forty-eight human rights cases, a total of forty-two cases were selected in which either (human rights) due diligence and/or (human rights) supply chain responsibilities

55. For example, the Dutch NCP's approach is progressive in that it accepts most cases and extends the scope of the MNE Guidelines if necessary (see Section 6.1).

56. In most cases multiple provisions were cited. were referenced or covered. Six cases were discarded for further analysis because they did not contain any reference to human rights due diligence or human rights supply chain responsibilities, but only cited other provisions of the Human Rights chapter.

\subsection{Data Collection}

Documents were collected and analysed in relation to all specific instances that were submitted to the Dutch NCP, UK NCP, German NCP, Danish NCP and Norwegian NCP in the period 2012-2018. The documents include initial assessments, final statements and any other available and relevant documents, such as the original notifications of the notifying parties. Documents were retrieved from the only three publicly accessible comprehensive databases provided by the Trade Union Advisory Committee to the OECD (TUAC), ${ }^{57}$ OECD Watch ${ }^{58}$ and the OECD. ${ }^{59}$

\subsection{Data Analysis}

The doctrinal research method has been applied to the analysis performed in this article. Doctrinal research is research 'into the law and legal concepts'. Through doctrinal research jurisprudence is analysed systematically. In this article, the decisions of NCPs are analysed by

57. TUAC provided a database of 191 trade union cases submitted under the OECD Guidelines since 2000, which are sorted by company, date or case status (available at: www.tuacoecdmneguidelines.org/cases.asp (last visited 25 June 2019)).

58. OECD Watch provides a case database on OECD Guidelines cases raised by civil society organisations at NCPS (available at: www.oecdwatch.org/cases (last visited 25 June 2019)).

59. OECD provides a database of specific instances handled by NCPs from 2000-2017 in over 100 countries, including those of interest for this study, namely UK, Germany, Denmark, and Norway (available at: http://mneguidelines.oecd.org/database/ (last visited 25 June 2019)). 
examining the rules established by the OECD about human rights due diligence and human rights supply chain responsibilities, the interpretation of these rules by NCPs, and the differences and similarities between the five selected NCPs in their argumentation. ${ }^{60}$ Since no method exists to analyse decisions of NCPs, it was decided to apply the doctrinal method, the limitation being that NCP decisions cannot be considered as jurisprudence or legal decisions. It is nevertheless expected that the systematic approach of the doctrinal research method can deliver similar results and insights as when applied to jurisprudence.

By analysing the argumentation of the Dutch NCP in the light of the argumentation applied by other NCPs, an attempt is made to assess the compatibility of these arguments with the MNE Guidelines. This study will therefore seek to find arguments deviating from or abiding by the provisions of the MNE Guidelines to assess their compatibility.

The NCP decisions are analysed using the template shown in Annex II. Each question in the template was answered for each specific instance. A matrix was prepared in which all the results were inserted. Questions 4, 8, 9 and 11 were particularly relevant to this study.

\section{Findings}

This section provides an analysis of the interpretation of the MNE Guidelines by the Dutch NCP in the light of the interpretations of the UK NCP, German NCP, Danish NCP and Norwegian NCP. Section 4.1 covers human rights due diligence, and Section 4.2 addresses human rights supply chain responsibilities. An overview of the main findings is given in Annex III.

\subsection{Human Rights Due Diligence}

\subsubsection{Dutch NCP: Interpretation of (Human Rights)} Due Diligence Provisions II.10 and IV.5

Provisions II.10 and IV.5 are the (human rights) due diligence provisions enshrined in the MNE Guidelines (see Table 1, Section 2.1). Time and again, the Dutch NCP is confronted with difficult questions it needs to answer when interpreting the scope of the MNE Guidelines. As analysed further on, in each instance the Dutch NCP interprets the general provisions on (human rights) due diligence (II.10 and IV.5) and then applies them to the case at hand, thereby occasionally extending the scope of the provisions to include new parties that fall under the (human rights) due diligence recommendations. A total of seven cases $^{61}$ were identi-

60. T. Hutchinson and N. Duncan, 'Defining and Describing What We Do: Doctrinal Legal Research', 17 Deakin Law Review 83, at 83-119 (2012).

61. Dutch NCP, Friends of the Earth v. Rabobank (2016); Dutch NCP, Bart Stapert v. Mylan (2016); Dutch NCP, Both Ends v. Atradius (2016); Dutch NCP, Individual from Ukraine v. Philips Lighting (2017); Dutch NCP, FIVAS, the Initiative to Keep Hasankeyf Alive and Hasankeyf fied, wherein the Dutch NCP decided on the subject of (human rights) due diligence. ${ }^{62}$

In FS FIVAS, the Initiative to Keep Hasankeyf Alive and Hasankeyf Matters v. Bresser, the Dutch NCP had to answer the question whether Bresser, a small and medium-sized enterprise (SME), falls within the scope of provision II.10. Citing the text of the MNE Guidelines, the Dutch NCP observes that the Concepts and Principles chapter of the MNE Guidelines states that 'SMEs should be encouraged to observe the [MNE] Guidelines' recommendations to the fullest extent possible'. ${ }^{63}$ SMEs should therefore also carry out (human rights) due diligence. Literally citing provisions II.2, the Dutch NCP reiterates that the nature and extent of due diligence depend on the circumstances of a particular situation and the severity of the risks. Carrying out due diligence is a responsibility of an SME, whereby the size may affect how it is executed. ${ }^{64}$

In Bart Stapert v. Mylan, the Dutch NCP had to decide whether provisions II.10 and IV.5 apply to the healthcare sector. The Dutch NCP endeavoured to clarify the due diligence provisions, particularly in cases of human rights abuses associated with the unintended use of medicines for lethal injections. ${ }^{65}$ In effect, the Dutch NCP decided that the (human rights) due diligence requirements equally apply to the healthcare sector. ${ }^{66}$

The Dutch NCP decided that besides their application to the health care sector, provisions II.10 and IV.5 also apply to the financial sector. In Friends of the Earth v. Rabobank, the Dutch NCP encouraged financial institutions to partake actively in due diligence initiatives in the financial sector in collaboration with NGOs. ${ }^{67} \mathrm{~A}$ few years earlier, the NCP decided that minority shareholders fall under the MNE Guidelines in the case of Various $N G O s$ v. $A B P / A P G$. As with any other investor, minority shareholders are expected to carry out riskbased due diligence 'prior to making a decision relating to lending, investing or other financial services to a client'. In this case, the NCP emphasises that the seemingly insignificant size of a shareholder, in this case $0.084 \%$, does not absolve the shareholder of the respon-

Matters v. Bresser (2018); Dutch NCP, Various NGOs v. ABP/APG (2013); Dutch NCP, Three individuals v. Heineken (2017).

62. On 8 May 2017, the Dutch NCP received a notification from Oxfam Novib, Greenpeace Netherlands, BankTrack and Friends of the Earth Netherlands claiming that ING did not act in accordance with the MNE Guidelines. In particular, ING was expected to conduct due diligence in relation to its climate impact, including ING's impact on its supply chains, to measure and disclose its direct and indirect carbon emissions, to reduce its indirect greenhouse gas emissions, and to align its emissions with the objectives of the Paris climate agreement. After mediation by the Dutch NCP, parties managed to reach an agreement on all these issues. This is the first specific instance in which a financial institution, i.e. ING, is expected to take action with regard to its indirect climate impacts, i.e. through ING's loans and investments. Despite its novel insights, the case falls outside the scope of this article, since the NCP issued its final statement in 2019.

63. Dutch NCP, FIVAS, the Initiative to Keep Hasankeyf Alive and Hasankeyf Matters v. Bresser (2018), at 5.

64. Ibid.

65. Dutch NCP, Bart Stapert v. Mylan (2016), at 2.

66. Ibid., at 5.

67. Dutch NCP, Friends of the Earth v. Rabobank (2016), at 4. 
sibility of carrying out due diligence. The MNE Guidelines do not make any exception. The Dutch NCP concluded that 'the [MNE] Guideline provisions on due diligence do apply to the financial sector, [and] the NCP finds that minority shareholders have a responsibility to perform a risk-based due diligence' ${ }^{68}$

After Friends of the Earth v. Rabobank and Various $N G O s$ v. $A B P / A P G$, the application of the due diligence recommendations of the MNE Guidelines for the financial sector was clear, but the application of the MNE Guidelines to (state-based) export credit agencies was not. In Both Ends v. Atradius, the principal issue was whether an insurance company, in this case the Dutch state's export credit agency, Atradius Dutch State Business (ADSB), could fall within the scope of the MNE Guidelines. The Dutch NCP decided that ADSB falls under the MNE Guidelines' definition of an MNE. Interestingly, the Dutch NCP demarcates the responsibility of export credit agencies in its final statement and shows that provisions II.10 and IV.5 deserve particular attention because the leverage of insurance companies is limited. The Dutch NCP articulates it as follows:

An insurance company assumes responsibility for its own ex ante due diligence, and will require its client ... to adhere to agreed principles and abide by contracts. It cannot however assume responsibility for acts performed by parties with which it has no relationship .... Since the leverage that can be exerted by insurance companies after issuing an insurance policy is limited, effective ex ante due diligence on all aspects of the proposed transaction, including the elements referred to in the $[\mathrm{MNE}]$ Guidelines, deserves their full attention and is the core business of insurance companies. ${ }^{69}$

\subsubsection{Other NCPs: Interpretation of (Human Rights) Due Diligence Provisions II.10 and IV.5}

Other NCPs have also grappled with the (human rights) due diligence provisions of the MNE Guidelines in different ways. (Human rights) due diligence was addressed in five cases before the Danish NCP, two of which are worth mentioning because they illustrate how the Danish NCP interprets provisions II.10 and IV.5. ${ }^{70}$ When interpreting the (human rights) due diligence provisions, the Danish NCP explains which elements were missing in order to carry out (human rights) due diligence. With regard to the Rana Plaza building collapse, a Danish MNE, PWT Group, was held responsible for not carrying out sufficient (human rights) due diligence due to the absence of risk and decision-making systems, inspections and site visits. ${ }^{71}$ In a rather unique

68. Dutch NCP, Various NGOs v. ABP/APG (2013), at 5 .

69. Dutch NCP, Both Ends v. Atradius (2016), at 5.

70. Danish NCP, Danish NGO v. Multinational Enterprise (Denmark) (2014); Danish NCP, Clean Clothes Campaign Denmark and Active Consumers v. PWT Group (2016); Danish NCP, Two NGOs v. Financial institution (2018); Danish NCP, Danish NCP v. Danish Ministry of Defence (2018); Danish NCP, Addameer v. Danish Subsidiary of a UK Multinational Enterprise Operating in Israel (2014).

71. Danish NCP, Clean Clothes Campaign Denmark and Active Consumers v. PWT Group (2016), at 8. case, the Danish NCP on its own initiative, investigated the (human rights) due diligence process of the Danish Ministry of Defence pertaining to the contracting and construction of an inspection vessel and associated forced labour. Despite the fact that the contract to build the inspection vessel dated back to 2004, the Danish NCP deemed the case admissible and applied the 2011 due diligence provisions. The Danish Ministry of Defence was held responsible for not conducting adequate (human rights) due diligence, mainly because it had not made probable that (human rights) due diligence was secured. ${ }^{72}$

Although the German NCP has dealt with six (human rights) due diligence cases, ${ }^{73}$ just one case offers more insights into how the German NCP interprets the (human rights) due diligence provisions. In this case, two German MNEs were held responsible for the lack of safety measures at Tazreen Fashion in Bangladesh, which led to the deaths of 112 people after a fire in 2012 . The German NCP supported the allegations that the claimant, a member of the German parliament, had against one of the MNEs, detailing a few elements that are necessary in fulfilling an MNE's duty of care, which is considered as a synonym for human rights due diligence. ${ }^{74}$ Avoiding subcontracts, determining the number of audits, reducing the number of suppliers, bolstering RBC within the MNE, ensuring compliance with the in-house code of conduct, having a clear strategy for improving the MNE's duty of care instead of shifting this responsibility to consumers, and having a sustainability report covering key $\mathrm{RBC}$ issues are all mentioned by the German NCP as key elements in improving an MNE's duty of care. ${ }^{75}$

Three $^{76}$ of the seven ${ }^{77}$ human rights due diligence cases dealt with by the Norwegian NCP add to the body of

72. Danish NCP, Danish NCP v. Danish Ministry of Defence (2018), at 3.

73. German NCP, ECCHR, Reporter ohne Grenzen, Bahrain Center for Human Rights, Bahrain Watch, Privacy International v. Trovicor GmbH (2014); German NCP, UK NGO v. MNE from Luxembourg (2015); German NCP, NGO v. German MNE (2015); German NCP, ECCHR, Medico International, FEMNET, GWUF, Comrade Rubel Memorial Center and five individuals of Rana Plaza v. a German MNE (2018); German NCP, UNI Global Union, International Transport Workers Federation v. Deutsche Post DHL (2014); German NCP, Uwe Kekeritz v. KiK Textilien und Non-Food GmbH, C\&A Mode GmbH \& Co. and Karl Rieker GmbH \& Co. KG (2014).

74. Cf. German NCP, NGO v. German MNE (2015), at 2.

75. German NCP, Uwe Kekeritz v. KiK Textilien und Non-Food GmbH, C\&A Mode GmbH \& Co. and Karl Rieker GmbH \& Co. KG (2014), at 7.

76. Norwegian NCP, Various NGOs v. Norwegian Bank Investment Management (2013); Norwegian NCP, United Steel Workers and Birlesik Metal IS v. Crown Holdings Inc. and Norges Bank Investment Management (2015); Norwegian NCP, Cotton Campaign, Anti-Slavery International, and KTNC Watch v. Daewoo International, POSCO and NBIM (2015).

77. Norwegian NCP, Sami Reindeer Herding Collective v. Statkraft AS (2014); Norwegian NCP, Various NGOs v. Norwegian Bank Investment Management (2013); Norwegian NCP, FIVAS v. Norpower (2015); Norwegian NCP, United Steel Workers and Birlesik Metal IS v. Crown Holdings Inc. and Norges Bank Investment Management (2015); Norwegian NCP, Cotton Campaign, Anti-Slavery International, and KTNC Watch v. Daewoo International, POSCO and NBIM (2015); Norwegian NCP, Industri Energi v. Det Norske Oljeselskapet (2016); Norwegian NCP, Norwegian Support Committee for Western Sahara v. Sjovik A.S. (2013) 
interpretation of provisions II.10 and IV.5. The three cases boil down to the same conclusion: the application of the (human rights) due diligence provisions of the MNE Guidelines to the financial sector, in general, and minority shareholders, specifically. According to the Norwegian NCP, the MNE Guidelines apply to all sectors and do not exempt subgroups of investors. ${ }^{78}$ Steps for human rights due diligence stipulated by the Commentaries of the MNE Guidelines are cited by the Norwegian NCP as the necessary steps to be taken. ${ }^{79}$ Human rights due diligence entails: (i) assessing actual and potential human rights impacts; (ii) integrating and acting on the findings; (iii) tracking responses; and (iv) communicating. Publicising a human rights due diligence strategy and ensuring that human rights due diligence includes the full range of human rights, not just a singular right such as child labour, may help in meeting provision IV.5. ${ }^{80}$

Being the NCP with the most (human rights) due diligence notifications (fifteen in total), the UK NCP further developed (human rights) due diligence by interpreting the MNE Guidelines in specific cases. The UK NCP provided more context as to when (human rights) due diligence is required. According to the UK NCP, executing appropriate (human rights) due diligence to prevent or cease an MNE's adverse contribution to human rights is necessary when there is a 'foreseeable' risk that an MNE adversely impacts human rights. ${ }^{81}$ When an MNE is trading or investing in weak governance zones, especially where ethnic tensions prevail, heightened care is warranted. (Human rights) due diligence may help identify possible negative effects of the MNE on human rights in these instances. ${ }^{82}$ Sometimes the UK NCP indicates when (human rights) due diligence is not necessary any more. In a case against a munition company, the UK NCP decided that the MNE's approach to rely on a UK government export licensing procedure and human rights risk assessment was sufficient for the MNE to meet its (human rights) due diligence obligations. ${ }^{83}$

Difficult to decipher are the decisions of the UK NCP in which the NCP introduces a responsibility to conduct 'general due diligence'. In the case involving a British MNE, the UK NCP found no link between the MNE's actions and the issues raised insofar that it would require any obligation 'beyond a general level of due diligence'. What this general level of (human rights) due diligence entails was not explained and why the UK NCP decided that the MNE had met this level was not

78. Norwegian NCP, Various NGOs v. Norwegian Bank Investment Management (2013), at 7.

79. OECD (2011b), above n. 20, at Procedural Guidance, Commentaries on Human Rights, at 45.

80. Norwegian NCP, Various NGOs v. Norwegian Bank Investment Management (2013), at 9-10 and 29.

81. UK NCP Steering Board, Reprieve v. British Telecommunications (2014), at 7

82. UK NCP, NGOs v. BTC Corporation (2011), at 50, 54, 61, 62 and 68.

83. UK NCP, Two NGOs v. UK Munition Company, at 24. clearly stated. ${ }^{84}$ The question why in this case the MNE met its (human rights) due diligence requirements remains unanswered.

\subsection{Human Rights Supply Chain Responsibilities}

\subsubsection{Dutch NCP: Interpretation of (Human Rights) Supply Chain Responsibility Provisions II.12, II.13 and IV.3}

Provisions II.12, II.13 and IV.3 are the (human rights) supply chain responsibility provisions enshrined in the MNE Guidelines (see Table 2, Section 2.2). As with the (human rights) due diligence provisions, the Dutch NCP applies provisions II.12, II.13 and IV.3 to the financial and healthcare sectors, extending the scope of the MNE Guidelines. In addition, the Dutch NCP sometimes provides guidelines on how to take responsibility in the various supply chains. A total of seven cases were identified, wherein the Dutch NCP decided on the subject of supply chain responsibilities. ${ }^{85}$

In FS FIVAS, the Initiative to Keep Hasankeyf Alive and Hasankeyf Matters v. Bresser, the Dutch NCP interprets provisions II.12 and IV.3 in relation to stakeholder consultation. In this specific case, the company, Bresser, had essential technical knowledge and unique experience, qualities that enabled Bresser to exert its leverage on a business relationship, which it neglected to do. The Dutch NCP recommended Bresser to use its leverage on its business relationships to ensure that meaningful stakeholder consultation took place and to adopt a more structured approach when consulting the local community, in order to prevent or mitigate any actual or potential adverse impacts. ${ }^{86}$ The Dutch NCP decisions, in fact, reinforced its earlier decision in Both Ends v. Atradius, whereby it encouraged export credit agency ADSB to utilise its leverage to stimulate stakeholder dialogue. ${ }^{87}$

We have already determined, in Section 4.1.1, that the MNE Guidelines also apply to the healthcare sector through the Dutch NCP's decision in Bart Stapert v. Mylan. In the same decision, the Dutch NCP interpreted the terms 'business relationship', as specified in provisions II.12 and IV.3. In the healthcare sector, the Dutch NCP stipulated that purchasers as well as distributors of medicines fall within the boundaries of a business relationship. Without any further elaboration, the NCP concluded that the MNE Guidelines are therefore applicable to 'both the supply chain and the distri-

84. UK NCP, Reprieve v. British Telecommunications I (2013), at 1, 2, 13 and 16; UK NCP Steering Board, Reprieve v. British Telecommunications (2014), at 6-7

85. Dutch NCP, FNV Eemshaven v. NUON (2014); Dutch NCP, Friends of the Earth v. Rabobank (2016); Dutch NCP, Bart Stapert v. Mylan (2016); Dutch NCP, Both Ends v. Atradius (2016); Dutch NCP, FIVAS, the Initiative to Keep Hasankeyf Alive and Hasankeyf Matters v. Bresser (2018); Dutch NCP, Various NGOs v. ABP/APG (2013); Dutch NCP, Sakhalin Environment Watch and Stroitel v. Royal Dutch Shell (2013).

86. Dutch NCP, FIVAS, the Initiative to Keep Hasankeyf Alive and Hasankeyf Matters v. Bresser (2018), at 5.

87. Dutch NCP, Both Ends v. Atradius (2016), at 7-8. 
bution chain'. ${ }^{88}$ Possibly, this extension to distribution chains widens the scope of the supply chain responsibilities, since distribution chains are not explicitly mentioned in the MNE Guidelines.

For the application of supply chain responsibilities in the financial sector, the Dutch NCP provides additional guidance by interpreting supply chain responsibilities in a number of cases. In Bart Stapert v. Mylan, the Dutch NCP observes how shareholders wield their power as investors and redress adverse impacts through their investment policies. Dialogue as well as disengagement by shareholders are perceived by the Dutch NCP as possible causes of improved conduct by Mylan. ${ }^{89}$ In Friends of the Earth v. Rabobank, financial institutions are expected to exercise individual leverage and to increase their leverage for their own clients to prevent or mitigate adverse impacts. With regard to business relationships, financial institutions are urged to engage in risk mitigation efforts, whereby disengagement by financial institutions is seen as a last resort..$^{90}$

Arguments applied by the Dutch NCP in Various NGOs v. $A B P / A P G$ are in line with the actual text of the human rights supply chain responsibilities provisions. Being directly linked to negative impacts on human rights and environmental rights through their investment, ABP/APG was responsible for seeking to prevent these negative impacts caused by their investee company. In conformity with provision II.12, the Dutch NCP argues that the responsibility of $\mathrm{ABP} / \mathrm{APG}$, according to the MNE Guidelines, is not intended to shift responsibility from the investee company to ABP/APG. Despite ABP/APG's minority shareholder position, it still has the responsibility to carry out due diligence (see Section 4.1.1) and to wield its power to prevent or mitigate adverse impacts. This is succinctly articulated by the Dutch NCP:

The (large total) size of its fund, its stated prominent role in international sustainable finance and its cooperation (including coalitions) with other similar funds in this case outweighs its small shareholding in the perspective of possible leverage with [the investee company] .... Concluding, it is not just the amount or percentage of financing which is an important consideration for the applicability of the [MNE] Guidelines, but also, or even rather so the degree of leverage by an investor (or lender) on the enterprise which 'caused or contributed' to the adverse impacts: such leverage may be very effectively applied by a large, high profile investor even if its participation is small in its own portfolio or in the enterprise. $^{91}$

In exceptional cases, supply chain responsibilities may transcend national legislation. In FNV Eemshaven v. NUON, the Dutch NCP concluded that the MNE Guidelines were more far-reaching than national legislation concerning the supply chain responsibilities of an

\footnotetext{
88. Dutch NCP, Bart Stapert v. Mylan (2016), at 5.

89. Ibid.

90. Dutch NCP, Friends of the Earth v. Rabobank (2016), at 4.

91. Dutch NCP, Various NGOs v. ABP/APG (2013), at 5
}

MNE for unfavourable labour circumstances at a subcontractor. According to Dutch legislation at the time, the commissioning MNE could not be held responsible for labour issues prevalent at its subcontractor, in this case the underpayment of wages by its subcontractor. ${ }^{92}$ By addressing this issue, the Dutch NCP identified a governance gap, a gap that was filled shortly thereafter, when a new bill was passed in parliament. ${ }^{93}$

\subsubsection{Other NCPs: Interpretation of (Human Rights) Supply Chain Responsibility Provisions II.12, II.13 and IV.3}

Other NCPs have also dealt with (human rights) supply chain responsibility cases. (Human rights) supply chain responsibilities were addressed in three cases before the Danish NCP ${ }^{94}$ one of which merited further consideration. ${ }^{95}$ Especially one of the two cases that was not accepted for further consideration, yields some interesting findings. In this case, the Danish NCP found that a financial institution continued to use its leverage to mitigate adverse impacts and eventually withdrew from a mining project. Using leverage and withdrawing from a project if no results are obtained is considered correct handling, in line with provision II.12 according to the Danish NCP. ${ }^{96}$

In five cases the German NCP addresses (human rights) supply chain responsibilities. ${ }^{97}$ Just as in the due diligence cases (see Section 4.1.2), the German NCP does not elaborate on how it interprets the (human rights) supply chain provisions. There is one notable exception, however, in which the German NCP restrictively interprets provision IV.3. In this case, the German NCP notes that "not every potential causal contribution to a human rights violation should be seen as a direct link as defined in Chapter IV ... paragraph 3, [of the MNE Guidelines]' and that the establishment of a 'direct link' must be assessed on a case-by-case basis. ${ }^{98}$

As regards the interpretation of a 'business relationship', the Norwegian NCP provides some guidance in three ${ }^{99}$

92. Dutch NCP, FNV Eemshaven v. NUON (2014), at 3.

93. The 2015 Sham Employment Arrangements Act (Wet aanpak schijnconstructies).

94. Danish NCP, Clean Clothes Campaign Denmark and Active Consumers v. PWT Group (2016); Danish NCP, Two NGOs v. Financial institution (2018); Danish NCP, Danish NCP v. Danish Ministry of Defence (2018)

95. Danish NCP, Clean Clothes Campaign Denmark and Active Consumers v. PWT Group (2016).

96. Danish NCP, Two NGOs v. Financial institution (2018), at 7.

97. German NCP, ECCHR, Reporter ohne Grenzen, Bahrain Center for Human Rights, Bahrain Watch, Privacy International v. Trovicor GmbH (2014); German NCP, UK NGO v. MNE from Luxembourg (2015); German NCP, NGO v. German MNE (2015); German NCP, ECCHR, Medico International, FEMNET, GWUF, Comrade Rubel Memorial Center and five individuals of Rana Plaza v. a German MNE (2018); German NCP, Uwe Kekeritz v. KiK Textilien und Non-Food GmbH, C\&A Mode $\mathrm{GmbH} \&$ Co. and Karl Rieker GmbH \& Co. KG (2014).

98. German NCP, UK NGO v. German MNE (2015), at 3.

99. Norwegian NCP, Various NGOs v. Norwegian Bank Investment Management (2013); Norwegian NCP, United Steel Workers and Birlesik Metal IS v. Crown Holdings Inc. and Norges Bank Investment Management (2015); Norwegian NCP, Cotton Campaign, Anti-Slavery International, and KTNC Watch v. Daewoo International, POSCO and NBIM (2015). 
of the four ${ }^{100}$ supply chain responsibility-related cases. Central to these three decisions is the Norwegian NCP's conclusion that a minority shareholder falls under the definition of a 'business relationship', as stipulated in provisions II.12 and IV.3 - even if this is not contemplated by the MNE Guidelines. The Norwegian NCP also establishes a nexus between the leverage to be exerted according to provisions II.12 and IV.3 and the execution of human rights due diligence. Insufficient leverage does not render (human rights) due diligence useless, according to the Norwegian NCP. On the contrary, (human rights) due diligence is recommended to find out precisely to what degree an MNE has leverage over its business relationships. ${ }^{101}$

A prerequisite for holding an MNE accountable for human rights infringements in its supply chain, according to provisions II.12 and IV.3, is the establishment of a direct connection between an MNE's business operations, products or services and human rights abuses by its business partners. ${ }^{102}$ In two specific instances, the UK NCP could not tie two banks to alleged human rights abuses, because of a missing link between the MNE's business operations, products or services and the provision of loans. ${ }^{103}$ When interpreting provisions II.12 and IV.3, the UK NCP shows that a direct link can be established in different ways. In a specific instance involving an MNE that offered security equipment to the Israeli government, the UK NCP did not establish a direct link between the product offered and alleged human rights abuses, but contracts concluded between the MNE and the Israeli government did constitute sufficient evidence to establish this direct link. As a consequence, the UK NCP was still able to apply provisions II.12 and IV.3. ${ }^{104}$ Yet, in another instance, three or fewer (press) articles, presumably based on unauthorised disclosures of information, without an MNE's endorsement and without any access to the source documents on which the articles were based, was considered as insufficient evidence to establish a direct link. ${ }^{105}$

Leverage is a central concept underlying (human rights) supply chain responsibilities. An MNE can exert significant leverage on its business partners when it wholly

100. Norwegian NCP, Various NGOs v. Norwegian Bank Investment Management (2013); Norwegian NCP, FIVAS v. Norpower (2015); Norwegian NCP, United Steel Workers and Birlesik Metal IS v. Crown Holdings Inc. and Norges Bank Investment Management (2015); Norwegian NCP, Cotton Campaign, Anti-Slavery International, and KTNC Watch v. Daewoo International, POSCO and NBIM (2015).

101. Norwegian NCP, Various NGOs v. Norwegian Bank Investment Management (2013); Norwegian NCP, FIVAS v. Norpower (2015), at 22; Norwegian NCP, United Steel Workers and Birlesik Metal IS v. Crown Holdings Inc. and Norges Bank Investment Management (2015), at 9-10; Norwegian NCP, Cotton Campaign, Anti-Slavery International, and KTNC Watch v. Daewoo International, POSCO and NBIM (2015), at 9-10.

102. For example, in a specific instance concerning the sabotage of local communities' water supplies by security forces of business partners (UK NCP, RAID v. ENRC (2016), at 57-66).

103. UK NCP, NGO v. UK Bank A (2012); UK NCP, NGO v. UK Bank B (2012).

104. UK NCP, Reprieve v. British Telecommunications III (2015).

105. UK NCP, UK NGO v. Six Telecommunications Companies (2014), at 44-6. owns a subsidiary, but also when it has acquired a 'controlling interest', i.e. when it has acquired at least $64 \%$ of the shares and has board positions in the other company. ${ }^{106}$ Under provision IV.3, an MNE cannot argue that it does not have any leverage over a government when its staff is not actively involved in the operations of that government, but nevertheless employs 8,000 people, provides services to 50,000 customers and has successfully lobbied for (employment) laws in the past. The UK NCP shows that leverage can still be exerted by

lobbying immediate business partners and/or government and legal representatives, sharing best practices (with business partners, stakeholders and the wider sector), and committing to new practices in regard to future contracts. ${ }^{107}$

In case an MNE cannot succeed in changing the behaviour of a business partner, the UK NCP emphasises that an MNE still has the responsibility to examine what it can do as it has the obligation to seek to prevent or mitigate an impact. ${ }^{108}$

\section{Discussion}

In this section, two points of discussion are highlighted. In Section 5.1, this article discusses whether the (extensive or restrictive) interpretation of the MNE Guidelines by the NCPs is warranted or not in the light of the effectiveness criterion 'compatibility with the MNE Guidelines'. In Section 5.2, this article discusses the diverging interpretations of the MNE Guidelines and the necessity of functional equivalence.

\subsection{The Compatibility of Interpretations}

All NCPs, except the German NCP, have added new elements to the (human rights) due diligence provisions. These provisions now apply to all sectors, whereby special attention in the cases discussed is paid to the financial and healthcare sectors, SMEs and minority shareholders are specified as stakeholders with (human rights) due diligence responsibilities, and contracts dating back to 2004, long before the MNE Guidelines were updated in 2011, still fall under the (human rights) due diligence responsibilities. All in all, we see how the scope of the MNE Guidelines is broadened by the various NCPs through their decisions by including all sectors, SMEs and minority shareholders as well as broadening the time frame to include cases before the last revision of the MNE Guidelines.

All NCPs have also added new elements to the (human rights) supply chain responsibility provisions. It has been made clear that SMEs can exert leverage when they have unique knowledge or expertise as well as

106. UK NCP, RAID v. ENRC (2016), at 40 and 66.

107. UK NCP, LHPR v. G4S (2015), at 68 and 70.

108. UK NCP, Crude Accountability v. KPO Consortium (2017), at 73. 
MNEs that have acquired a 'controlling interest'. Conducting (human rights) due diligence may be auxiliary to finding out what degree of leverage an MNE has over its business relationships, whereby withdrawing from a project may be the ultimate measure taken by an MNE. The text of the MNE Guidelines has been underlined, by stressing that having no leverage is no excuse, because MNEs still have the responsibility to seek to prevent or mitigate adverse impacts. These cases teach us that an MNE's responsibility to wield its power to influence business partners is far-reaching - maybe more far-reaching than the MNE Guidelines suggest.

All these new interpretations extend the scope of the MNE Guidelines and, in some instances, underpin the text of the MNE Guidelines. Arguably, NCPs should be hesitant to add new elements or to restrict the interpretation of the MNE Guidelines. MNEs could argue that an extensive interpretation of the MNE Guidelines imposes responsibilities that do not exist in the MNE Guidelines, whereas NGOs could argue that a restrictive interpretation may hamper the development of the MNE Guidelines and exempt MNEs from their responsibilities. One could refute these arguments by stating that these restrictions and extensions of the MNE Guidelines are essential because of the sometimes vague nature of wordings of the MNE Guidelines and because NCPs have to interpret the MNE Guidelines in order to reach a conclusion in individual cases. Be this as it may, the interpretations of the MNE Guidelines may not always be compatible with the MNE Guidelines which, once again, is a matter of interpretation.

\subsection{The Issue of Functional Equivalence}

Perhaps one of the most important questions in the light of the foregoing concerns the application of functional equivalence. Being one of the cornerstones of NCPs, functional equivalence is paramount to the functioning of the entire specific instance system. For instance, if the Dutch NCP decides to extend the scope of human rights due diligence to the financial sector and the German NCP decides the exact opposite, a claimant would not be treated equally by the NCPs. This begs the question whether new interpretations of an NCP will also be adopted by its counterparts. NCPs rarely cite other NCPs in their decisions and it is not clear whether they are aware of the decisions made in other countries. This possible unawareness could become problematic if it leads to diverging interpretations of the MNE Guidelines and thus to a degradation of functional equivalence. It becomes extra problematic if domestic governments attach consequences to NCP decisions within the context of policy coherence and if these consequences differ per NCP for identical violations of the MNE Guidelines.

\section{Conclusions and Future Research}

In this section the main research question is briefly answered (Section 6.1) and a number of avenues for future research are provided (Section 6.2).

\subsection{Conclusions}

After analysing the arguments of the various NCPs, it is possible to answer the main research question.

In furthering the MNE Guidelines, it is concluded that the Dutch NCP is one of the most innovative NCPs. It not only applies a broad interpretation of the scope of (human rights) due diligence and (human rights) supply chain responsibility provisions, but also does not shy away from applying the MNE Guidelines in the absence of legislation. Similar to the Norwegian NCP and UK NCP, the Dutch NCP supports its decisions with arguments adding to the body of interpretation of the MNE Guidelines. In contrast, the German NCP rarely discloses its interpretation of the MNE Guidelines in a way that would produce new insights.

The analysis in the previous sections predominantly shows that decisions are coherent as a whole and complementary to each other, insofar as they do not contradict other decisions. For example, the body of interpretation created by all NCPs with regard to terminology such as 'leverage' or 'direct link' has been complementary to each other, creating clearer guidelines for interpretation. In this manner, the MNE Guidelines, as a soft law instrument, are interpreted by various NCPs, thereby adding to the body of interpretation of the MNE Guidelines, which is then applicable to all NCPs if they are to function equally (i.e. functional equivalence). The UK NCP's consideration about 'general due diligence', however, remains an exception. It is only applied by the UK NCP in one decision, and not by other NCPs, and the UK NCP does not clearly delineate the differences between due diligence of the MNE Guidelines and 'general due diligence' developed by the UK NCP.

This study revealed how the various NCPs interpret the MNE Guidelines and how they sometimes stick to the text of the provisions by citing them in cases. It is concluded that these citations ensure the compatibility of the NCPs' decisions with the MNE Guidelines. It becomes more complex when interpretations restrict or extend the provisions of the MNE Guidelines. On the one hand, extending human rights supply chain responsibilities to minority shareholders, for example, may unnecessarily burden them to use their leverage. On the other hand, the German NCP's interpretation of a direct link, arguing that not every potential causal contribution to a human rights violation should be seen as a direct link, may form a basis for rejecting a lot of cases that would otherwise be accepted by another NCP. In both examples, and similar extensions or restrictions, NCPs should be careful not to limit the MNE Guidelines, but to let their interpretations be conducive 
to stimulating $\mathrm{RBC}$ in order to assume compatibility with the goal of the MNE Guidelines.

\subsection{Future Research}

This study provides a few avenues for future research. First of all, other NCPs could be investigated that have not been included in this study. Some NCPs, such as the US NCP, have a vast body of decisions that may be worth looking at.

Against the backdrop of the effectiveness criterion 'compatibility with the MNE Guidelines', it would be interesting to look at the interpretation of other chapters by the five NCPs covered in this study as well as other NCPs. Multiple questions can be raised, such as the following: Are NCPs citing the provisions or are they extending or restricting the MNE Guidelines' provisions in these cases? Is the body of interpretation complementary to each other or conflicting?

What made this research difficult is the differing amount of cases per NCP, tainting their comparability. If the NCPs decide on more human rights cases, our study could be replicated in a couple of years. For NCPs with a small number of cases, such as the Danish NCP, it could be helpful to check whether the results of this study can still be upheld when the number of closed cases increases.

A last avenue for future research relates to a key aspect of the MNE Guidelines, namely functional equivalence. It would be useful to examine all decisions of NCPs per provision to check whether the interpretation is similar. If this is not the case, the interpretation of the MNE Guidelines becomes uneven, which is detrimental to the functional equivalence of NCPs. It would also be useful to examine the policy coherence measures undertaken by the domestic governments to determine whether consequences are attached to certain decisions. Ways to improve functional equivalence and policy coherence across more NCPs and their governments could be part of future research. 


\section{Annex I}

Human Rights Provisions MNE Guidelines

\begin{tabular}{ll}
\hline Provision & Text \\
\hline Chapter II General Policies & \\
\hline II.2 & [Enterprises should] respect the internationally recognised human rights of those affected by their activi- \\
& ties. \\
\hline II.5 & $\begin{array}{l}\text { [Enterprises should] refrain from seeking or accepting exemptions not contemplated in the statutory or } \\
\text { regulatory framework related to human rights, environmental, health, safety, labour, taxation, financial } \\
\text { incentives, or other issues. }\end{array}$ \\
\hline II.10 & $\begin{array}{l}\text { [Enterprises should] carry out risk-based due diligence, for example by incorporating it into their enter- } \\
\text { prise risk management systems, to identify, prevent and mitigate actual and potential adverse impacts as } \\
\text { described in paragraphs } 11 \text { and 12, and account for how these impacts are addressed. The nature and } \\
\text { extent of due diligence depend on the circumstances of a particular situation. }\end{array}$ \\
\hline
\end{tabular}

[Enterprises should] avoid causing or contributing to adverse impacts on matters covered by the Guidelines, through their own activities, and address such impacts when they occur.

II.12 [Enterprises should] seek to prevent or mitigate an adverse impact where they have not contributed to that impact, when the impact is nevertheless directly linked to their operations, products or services by a business relationship. This is not intended to shift responsibility from the entity causing an adverse impact to the enterprise with which it has a business relationship.

II.13 In addition to addressing adverse impacts in relation to matters covered by the Guidelines, [enterprises should] encourage, where practicable, business partners, including suppliers and sub-contractors, to apply principles of responsible business conduct compatible with the Guidelines.

\section{Chapter IV Human Rights}

IV.1 [Enterprises should] Respect human rights, which means they should avoid infringing on the human rights of others and should address adverse human rights impacts with which they are involved.

IV.2 [Enterprises should] Within the context of their own activities, avoid causing or contributing to adverse human rights impacts and address such impacts when they occur.

IV.3

[Enterprises should] Seek ways to prevent or mitigate adverse human rights impacts that are directly linked to their business operations, products or services by a business relationship, even if they do not contribute to those impacts.

IV.4 [Enterprises should] have a policy commitment to respect human rights.
text of operations and the severity of the risks of adverse human rights impacts. 


\section{Annex II}

Template Doctrinal Research

1. Parties involved?

2. Countries (where the parties or the parties' headquarters are located)?

3. When was the complaint made, was an agreement reached? If so, what was the end date?

4. What was the outcome? By which NCP? What does the outcome entail (outcome matches complaint, takes into account considerations)?

5. Which NCP was competent to deal with the instance?

6. Fact-finding or not?

7. Did a hearing take place? Did the parties convene?

8. What was the complaint about?

9. Which norms of the MNE Guidelines were referred to in the case? If applicable, what other norms were referred to, such as the Global Compact, the UN Guiding Principles, international treaties, regional treaties?

10. Existing parallel (legal) procedures?

11. Reference to similar decisions of the NCP or other NCPs (consistency with previous decisions)?

12. Follow-up/enforcement? 


\section{Annex III}

Overviem Findings

\begin{tabular}{|c|c|c|c|c|c|}
\hline & Dutch NCP & UK NCP & German NCP & Danish NCP & Norwegian NCP \\
\hline \multirow[t]{4}{*}{$\begin{array}{l}\text { (Human rights) } \\
\text { due diligence }\end{array}$} & $\begin{array}{l}\text { (Human rights) } \\
\text { due diligence also } \\
\text { applies to SMEs }\end{array}$ & $\begin{array}{l}\text { (Human rights) due dili- } \\
\text { gence is necessary } \\
\text { when there is a 'fore- } \\
\text { seeable' risk that an } \\
\text { MNE adversely impacts } \\
\text { human rights }\end{array}$ & \multirow{3}{*}{$\begin{array}{l}\text { (Human rights) due dili- } \\
\text { gence can be strength- } \\
\text { ened by: avoiding sub- } \\
\text { contracts, determining } \\
\text { the number of audits, } \\
\text { reducing the number of } \\
\text { suppliers, bolstering } \\
\text { RBC within the MNE, } \\
\text { ensuring compliance } \\
\text { with the in-house code } \\
\text { of conduct, having a } \\
\text { clear strategy for } \\
\text { improving the MNE's } \\
\text { duty of care instead of } \\
\text { shifting this responsibili- } \\
\text { ty to consumers, and } \\
\text { having a sustainability } \\
\text { report covering key RBC } \\
\text { issues }\end{array}$} & $\begin{array}{l}\text { The absence of } \\
\text { risk and decision- } \\
\text { making systems, } \\
\text { inspections and } \\
\text { site visits may lead } \\
\text { to insufficient } \\
\text { (human rights) } \\
\text { due diligence }\end{array}$ & $\begin{array}{l}\text { (Human rights) } \\
\text { due diligence } \\
\text { applies to all sec- } \\
\text { tors }\end{array}$ \\
\hline & $\begin{array}{l}\text { (Human rights) } \\
\text { due diligence also } \\
\text { applies to the } \\
\text { healthcare sector }\end{array}$ & $\begin{array}{l}\text { When an MNE is trad- } \\
\text { ing or investing in weak } \\
\text { governance zones, } \\
\text { especially where ethnic } \\
\text { tensions prevail, height- } \\
\text { ened care is warranted, } \\
\text { and thus the need for } \\
\text { (human rights) due dili- } \\
\text { gence }\end{array}$ & & $\begin{array}{l}\text { In order to meet } \\
\text { the (human rights) } \\
\text { due diligence } \\
\text { responsibilities it } \\
\text { should be made } \\
\text { probable that } \\
\text { (human rights) } \\
\text { due diligence is } \\
\text { secured }\end{array}$ & $\begin{array}{l}\text { (Human rights) } \\
\text { due diligence also } \\
\text { applies to the } \\
\text { financial sector and } \\
\text { minority share- } \\
\text { holders }\end{array}$ \\
\hline & $\begin{array}{l}\text { (Human rights) } \\
\text { due diligence also } \\
\text { applies to the } \\
\text { financial sector } \\
\text { and minority } \\
\text { shareholders }\end{array}$ & $\begin{array}{l}\text { In some instances, } \\
\text { (human rights) due dili- } \\
\text { gence does not have to } \\
\text { go 'beyond a general } \\
\text { level' of (human rights) } \\
\text { due diligence }\end{array}$ & & & \\
\hline & $\begin{array}{l}\text { (Human rights) } \\
\text { due diligence also } \\
\text { applies to (state- } \\
\text { based) export } \\
\text { credit agencies }\end{array}$ & & & & \\
\hline \multirow[t]{2}{*}{$\begin{array}{l}\text { (Human rights) } \\
\text { supply chain } \\
\text { responsibilities }\end{array}$} & $\begin{array}{l}\text { SMEs can exert } \\
\text { leverage, because } \\
\text { of essential techni- } \\
\text { cal knowledge and } \\
\text { unique experience }\end{array}$ & $\begin{array}{l}\text { Three or fewer (press) } \\
\text { articles, presumably } \\
\text { based on unauthorised } \\
\text { disclosures of infor- } \\
\text { mation, without an } \\
\text { MNE's endorsement } \\
\text { and without any access } \\
\text { to the source docu- } \\
\text { ments on which the } \\
\text { articles were based, } \\
\text { may be insufficient to } \\
\text { establish a direct link }\end{array}$ & $\begin{array}{l}\text { Not every potential } \\
\text { causal contribution to a } \\
\text { human rights violation } \\
\text { should be seen as a } \\
\text { direct link. A direct link } \\
\text { should be established } \\
\text { on a case-by-case basis }\end{array}$ & $\begin{array}{l}\text { (Human rights) } \\
\text { supply chain } \\
\text { responsibilities } \\
\text { may be met if an } \\
\text { MNE uses its } \\
\text { leverage and with- } \\
\text { draws from a pro- } \\
\text { ject if no results } \\
\text { are obtained }\end{array}$ & \multirow[t]{2}{*}{$\begin{array}{l}\text { Insufficient lever- } \\
\text { age does not ren- } \\
\text { der (human rights) } \\
\text { due diligence use- } \\
\text { less. (Human } \\
\text { rights) due dili- } \\
\text { gence could be } \\
\text { carried out to find } \\
\text { out precisely to } \\
\text { what degree an } \\
\text { MNE has leverage } \\
\text { over its business } \\
\text { relationships }\end{array}$} \\
\hline & $\begin{array}{l}\text { Leverage may be } \\
\text { used to stimulate } \\
\text { stakeholder dia- } \\
\text { logue }\end{array}$ & $\begin{array}{l}\text { Contracts between an } \\
\text { MNE and government } \\
\text { may establish a direct } \\
\text { link }\end{array}$ & & & \\
\hline
\end{tabular}




\begin{tabular}{|c|c|c|c|c|}
\hline Dutch NCP & UK NCP & German NCP & Danish NCP & Norwegian NCP \\
\hline $\begin{array}{l}\text { (Human rights) } \\
\text { supply chain } \\
\text { responsibilities } \\
\text { apply to both the } \\
\text { supply chain and } \\
\text { the distribution } \\
\text { chain }\end{array}$ & $\begin{array}{l}\text { An MNE can exert sig- } \\
\text { nificant leverage on its } \\
\text { business partners when } \\
\text { it wholly owns a subsid- } \\
\text { iary and when it has } \\
\text { acquired a 'controlling } \\
\text { interest' }\end{array}$ & & & \\
\hline $\begin{array}{l}\text { (Human rights) } \\
\text { supply chain } \\
\text { responsibilities } \\
\text { apply even if these } \\
\text { responsibilities are } \\
\text { not enacted in } \\
\text { national legislation }\end{array}$ & $\begin{array}{l}\text { Leverage can be exer- } \\
\text { ted by 'lobbying imme- } \\
\text { diate business partners } \\
\text { and/or government and } \\
\text { legal representatives, } \\
\text { sharing best practices, } \\
\text { and committing to new } \\
\text { practices in regard to } \\
\text { future contracts' }\end{array}$ & & & \\
\hline
\end{tabular}

\section{(Human rights)}

supply chain

responsibilities also

apply to the finan-

cial sector and

minority share-

holders

\section{(Human rights)}

supply chain

responsibilities also

apply to the

healthcare sector

\begin{tabular}{|c|c|c|c|}
\hline Other & $\begin{array}{l}\text { (State-based) } \\
\text { export credit } \\
\text { agencies fall under } \\
\text { the definition of } \\
\text { an MNE }\end{array}$ & $\begin{array}{l}\text { Notification submitted } \\
\text { by a Member of } \\
\text { Parliament and accept- } \\
\text { ed by the German NCP }\end{array}$ & $\begin{array}{l}\text { Danish NCP on its } \\
\text { own instigation } \\
\text { started a specific } \\
\text { instance against } \\
\text { the Danish gov- } \\
\text { ernment }\end{array}$ \\
\hline & & & $\begin{array}{l}\text { Application of the } \\
2011 \text { MNE } \\
\text { Guidelines to a } \\
\text { contract of } 2004\end{array}$ \\
\hline
\end{tabular}

